\title{
On Lines of Flight: The Theory of Political Transformation in A Thousand Plateaus
}

\author{
Edward Thornton \\ Deleuze and Guattari Studies, Volume 14 Issue 3 \\ Page 433-456 \\ ISSN 2398-9777 \\ Available Online Aug 2020 \\ https://doi.org/10.3366/dlgs.2020.0411
}

\begin{abstract}
:
The concept of the line of flight is used with striking regularity throughout $A$ Thousand Plateaus where it plays a vital role in connecting the other conceptual innovations of the book, including the concepts of the assemblage and the machine. Despite its importance, Deleuze and Guattari never offer a direct definition of the concept, and the reader of $A$ Thousand Plateaus is left to discern its meaning from its various uses. This is especially frustrating for those whose interest in the text is political and who wish to use the conceptual framework of the book to analyse the socio-political assemblages in which they live. In response to this issue, this paper offers a clear and concise introduction to the concept of the line of flight. Furthermore, by analysing the way in which Deleuze and Guattari use this concept in their political analyses of feudalism and capitalism, this article illuminates the more general meaning of the concept of the line of flight through the more specific question of its usage in Deleuze and Guattari's attempt to think a post-capitalist future.
\end{abstract}

\section{Introduction:}

While $A$ Thousand Plateaus does not carry the same revolutionary tone as AntiOedipus, it is still a book of political promise. Rather than having disappeared, Deleuze and Guattari's political desire to produce a new, post-capitalist mode of life displays itself in $A$ Thousand Plateaus as part of a much wider reconceptualisation of the social field. One way to discern the shift that has occurred, and to root out the sections of the latter book that provide an analysis of political change, is to pay attention to the concept of the 'line of flight' (ligne de fuite). ${ }^{1}$

Deleuze and Guattari invented the concept of the line of flight in Anti-Oedipus in order to pick out the specific way in which unconscious desire continually escapes from the Oedipal triangulation of contemporary capitalism, signalling to us the possibility of a post-capitalist future (2012, 306-311). In A Thousand Plateaus, the concept of the line of flight - along with the associated concepts of the assemblage, the machine, and 
machinic becoming - are developed and reapplied in order to allow Deleuze and Guattari to conceptualise change at all levels of reality, be they physical, organic, or socio-political. What we find in A Thousand Plateaus is that the world is composed of assemblages of various kinds and that change occurs when these assemblages interact with one another in a particular way. More specifically, assemblages are composed of lines; the lines that escape the boundaries of one assemblage, and allow it to connect up with another assemblage, are called lines of flight. These assemblages are not to be understood as mechanistic, or as being animated by some kind of vitalist force that is external to them. Instead, the assemblages are 'machinic', in the sense that Deleuze and Guattari had used the term in Anti-Oedipus (2012, 313). As such, transformations can only occur in assemblages when a line of flight connects one assemblage to another and instigates a mutual becoming between the two. As Deleuze and Guattari put it, 'an assemblage never contains a causal infrastructure', but it does contain 'an abstract line of creative or specific causality, its line of flight', by which it can transform itself $(2004,312){ }^{2}$

In this paper, I will show how Deleuze and Guattari apply this mode of analysis to social formations. My aim here will be to explain the political theory that is implicit in $A$ Thousand Plateaus and to show the specific role that the concept of the line of flight plays in that theory. I will begin with an analysis of the concept of the line of flight as it relates to machinic becoming. In order to do this, I will take the well-known example of the mutual becoming of the wasp and the orchid, which Deleuze and Guattari discuss in both Anti-Oedipus (2012, 313-314) and A Thousand Plateaus (2004, 1113). Following this, in section two, I will discuss Deleuze and Guattari's characterisation of social formations as assemblages, showing how they repeat many of the same dynamics as the wasp-orchid assemblage, but at the level of sociopolitical interaction. Here I will also go into some detail concerning the nature of these political assemblages, first by explaining Deleuze and Guattari's distinction between a 'machinic assemblage of bodies' and a 'collective assemblage of enunciation' (2004, 97-98), and secondly by showing how this distinction is operative in Deleuze and Guattari's analysis of feudalism. In section three I will add another layer of complexity to this analysis by paying close attention to the four different 'regimes of signs' that Deleuze and Guattari introduce in order to analyse the political implications of collective assemblages of enunciation $(2004,123)$. At this point, we will be in a position to see how Deleuze and Guattari define capitalism in A Thousand Plateaus and how they see lines of flight as both central to the operation of capitalism and also as the potential points of escape from capitalism. In the fourth and final section of the paper, I will discuss the various modes of becoming that Deleuze and Guattari advocate in the book - from becoming-woman and becoming-animal, to becoming-imperceptible - and show how each of these becomings occurs on a line of flight, which opens the possibility of an anti-capitalist mode of subjectivity. As a whole, this paper can be understood as an analysis of Deleuze and Guattari's concept of the line of flight, as it relates to the anti-capitalist politics of $A$ Thousand Plateaus. 


\section{Lines of Flight in the Machinic Becoming of Assemblages}

In an interview in 1980, Deleuze refers to the concept of the assemblage (agencement) as a the 'general logic' that underpins $A$ Thousand Plateaus $(1980,99)$. Through the use of this term, Deleuze and Guattari attempt to analyse the way in which reality is composed not of a general taxonomy of individual objects, but of arrangements or constructions of heterogeneous elements. An assemblage is not a unified whole, but a combination that functions by bringing together elements of various levels, and which is defined by the external relations that it holds with other assemblages. ${ }^{3}$ Deleuze and Guattari refer to assemblages as 'machinic' because, like machines, they are made up of different parts, which work together to produce an effect and, also like machines, their singular nature is determined by the way in which they uphold relations with what is outside of themselves. A car is composed of various working parts, but the way in which these parts are combined produces effects that exceed the capabilities of the individual parts. The car is also defined by the functional role it plays in combining people, roads, petrol, and various other elements. ${ }^{4}$ As Thomas Nail puts it: 'In contrast to organic unities, for Deleuze and Guattari, assemblages are more like machines, defined solely by their external relations of composition, mixture, and aggregation. In other words, an assemblage is a multiplicity, neither a part nor a whole' (Nail 2017, 23).

A second reason that Deleuze and Guattari refer to assemblages as operating via machinic processes is that it allows them to escape from the misconceptions of both mechanistic and vitalist theories of matter (Colebrook 2009, 1-33). For Deleuze and Guattari, mechanistic theories are those that explain material processes as a series of combinations and collisions of inert elements, such as atoms, whereas vitalist theories are those that explain material processes by way of a teleological force that runs through matter and orientates it. In contrast to both of these frameworks of understanding, Deleuze and Guattari's machinism does not separate inert matter from a force that works upon it. ${ }^{5}$ In Anti-Oedipus, where the concept of the machine is first developed in order to offer a new theory of desire, Deleuze and Guattari write that this concept 'shatters the vitalist argument by calling into question the specific or personal unity of the organism, and the mechanist argument... by calling in question the structural unity of the machine' $(2012,313) .{ }^{6}$ So, in brief, we can say that for Deleuze and Guattari, the world is composed of assemblages of various elements, which combine and interact through a series of machinic relations.

Because these machinic assemblages are not unified objects, and because they are composed of other machines which are similarly multiple, Deleuze and Guattari must develop a new vocabulary for analysing them. It is for this reason that they introduce the terminology of lines. In A Thousand Plateaus, Deleuze and Guattari claim that 'what constitutes an assemblage' is a collection of 'lines' $(2004,4)$. Here they also claim that it is possible to distinguish between three different kinds of lines in any assemblage: 'Line of molar or rigid segmentarity, line of molecular or supple 
segmentation, line of flight' $(2004,225)$. For an assemblage to exist, it must be the case that some of the lines, or connections, that make up the assemblage serve to sustain its structure. These lines, which hold the assemblage together, are referred to as lines of rigid segmentarity, or molar lines. On the other hand, for the assemblage to reproduce itself in such a way that it survives over time, it must also be able to adapt or change. The lines which bring about these revisions are referred to as lines of supple segmentation, or molecular lines. Finally, there are those lines that reach outside of the assemblage, those parts of the assemblage that escape the structure of which they are a part, and which serve to connect such an assemblage up to that which is outside itself. These lines are referred to as lines of flight. Because machinic assemblages are defined by the external relations that they maintain with other machines, these lines of flight are an essential component of the assemblage. As Deleuze and Guattari put it: 'It is clear that the line of flight does not come afterward; it is there from the beginning' $(2004,226)$. As a first approximation then, we can say that lines of flight are those relations that reach outside of an assemblage and allow it to make machinic connections with the assemblages that constitute its environment.

In order to flesh out the terminology of 'assemblages', 'machines', and 'lines of flight', and in order to show how these concepts relate to the process of 'becoming', it will be useful to take an example. In Anti-Oedipus and in A Thousand Plateaus, Deleuze and Guattari return to the example of the mutual development of certain species of wasps and certain species of orchids to explain what they mean by the concept of the line of flight, and how it is operative in processes of machinic becoming (2012, 313-314; 2004, 11-13). So, what is a wasp according to Deleuze and Guattari's analysis? A wasp is an assemblage composed of three different kinds of lines. First, in order to give a genetic account of the production of the wasp assemblage, we must recognise that there are certain processes that serve to reproduce the form of the wasp. At the level of the chemical, there is the repetition of strings of genetic code; at the level of the social, there are the rules that separate workers from queens and serve to reproduce the collective status quo. These are two of the molar or rigid lines of the wasp assemblage. However, in order for wasps to exist at all, they must also be able to adapt and to adjust themselves to changing conditions: the repetition of the genetic code must contain a certain level of mutation, and the social rules must be supple enough to allow an old queen to be replaced when necessary. These are the molecular lines of supple segmentation. Finally, however, the wasp assemblage is also constituted by the way in which it upholds connections with its outside. For example, wasps rely on plants for their food and plants rely on wasps for pollination. During the 'aparallel evolution' of the wasp and the orchid, the two assemblages becomes intertwined when the orchid begins to reproduce the image of a wasp on its petals to which other wasps are sexually attracted $(2004,11)$. In this process, the orchid 'deterritorializes by forming an image, a tracing of a wasp', while the wasp 'reterritorializes the orchid by transporting its pollen'. In this way, the wasp can be understood as 'becoming a piece in the orchid's reproductive apparatus' $(2004,11)$. Deleuze and Guattari's point here is that these interspecies connections are an 
essential part of the development of the apparently independent species. To put this another way, we can say that the wasp-assemblage is partially constituted by its lines of flight, which do not come afterwards, but are in integral part of the production of the species.

Deleuze and Guattari borrow this example from the work of Samuel Butler, who helps them to elucidate the machinic character of organic life. In his satirical science-fiction novel Erewhon, Butler makes the point that humans and machines are intertwined in much the same way that plants and pollinators are intertwined. Orchids cannot reproduce themselves without wasps, and wasps cannot survive without orchids, but we do not say that the orchid lacks a reproductive system of its own. Butler concludes that 'the bare fact that no vapour-engine was ever made entirely by another, or two others, of its own kind, is not sufficient to warrant us in saying that vapour-engines have no reproductive system', and that in fact humans are part of 'the mechanical reproductive system' of these machines (Butler, 1965, 146-60). ${ }^{7}$ Organic life is machinic and species-assemblages are constituted in part by their lines of flight.

The example of the wasp and the orchid can also help us to understand what Deleuze and Guattari mean by the term 'becoming'. When the orchid evolves to reproduce the image of the wasp on its petals, it is not enough to say that it is simply imitating the wasp. The orchid is quite literally transforming itself into part of the wasp-assemblage, while the wasp is becoming part of the orchid-assemblage. In keeping with their machinic analysis of assemblages, Deleuze and Guattari will say that in this process there is 'neither imitation nor resemblance' but only 'an exploding of the two heterogeneous series on the line of flight', by which there is both 'a becoming-wasp of the orchid and a becoming-orchid of the wasp' $(2012,11)$. These processes of becoming are not be understood as intentional or teleological, but as the unintended machinic effects that are produced when a line of flight connects one assemblage with another. In line with their analysis of desire in Anti-Oedipus, in A Thousand Plateaus Deleuze and Guattari are clear that machines only develop by 'breaking down' (2012, 219 ; 298). Just as evolution relies on the mutations that occur when genetic code is incorrectly reproduced, transformations of machines always rely on a break down. The wasp's sexual attraction to the orchid is like a perversion, but one which produces a new connection that will transform the whole species. This is what a line of flight is: it is an operation or a breakdown of a machinic assemblage, which reaches outside of that assemblage, connects it up with another assemblage, and instigates a mutual process of becoming, by which a transformation occurs.

\section{Transformation in Socio-Political Assemblages}

In A Thousand Plateaus, Deleuze and Guattari are clear that lines of flight do not only relate to the transformation of organic bodies, but that they also exist at the social level: 'Lines of flight are immanent to the social field' $(2004,227)$. What is more, Deleuze and Guattari will claim that it is by looking at how different societies deal with 
their lines of flight that we can distinguish between different social forms. They write that 'a social field is defined less by its conflicts and contradictions than by the lines of flight running through it' $(2004,100)$. This statement marks a certain kind of break from the traditional Marxist claim that the historical development of different modes of production progresses due to the existence of internal contradictions in each system. In an introduction that he wrote for Marx's Capital Volume 1, Ernest Mandel offers us a clear picture of the theory that Deleuze and Guattari are rejecting: according to Mandel, the 'laws of motion of the given mode of production' are nothing other than 'the unfolding of the inner contradictions of that structure, which define its very nature' $(18,1990)$. In a move that can be seen as an attempt to purge Marxist theory of its latent Hegelianism, Deleuze and Guattari reject the supposed prominence of internal contradictions and replace the transformative role played by them with the concept of the line of flight. This move is part of a larger critique of Marxist theory, in which Deleuze and Guattari reject the traditional distinction between a society's material base and its ideological superstructure. In place of this distinction, Deleuze and Guattari substitute an analysis of social forms as assemblages, much like the assemblage of the wasp, which combine heterogeneous elements and which are defined by the external relations that they maintain with their outside. Just as the concept of the line of flight allowed Deleuze and Guattari to theorise biological and organic transformations as integral parts of the assemblage of the species that they compose, in A Thousand Plateaus the authors will also use the concept of the line of flight to explain political transformations as part of the dynamic infrastructure of the social field.

While Deleuze and Guattari are clear that '[a]n assemblage has neither base nor superstructure', they recognise that any socio-political assemblage combines heterogenous elements that include both corporeal and incorporeal aspects (2004, 100). To describe these two sides of the assemblage, Deleuze and Guattari speak of the difference between a 'machinic assemblage of bodies' and a 'collective assemblage of enunciation' (2004, 97-100). While Marx had spoken of the base of society as being composed of the productive capacities of its material elements including the land, machines, tools, and technology of that society - Deleuze and Guattari will claim that 'the material or machinic aspect of an assemblage relates not to the production of goods but rather to a precise state of intermingling of bodies in a society' $(2004,100)$. The exact way in which bodies are intermingled is determined in part by the modes of enunciation of that society. As Deleuze and Guattari put it, 'the semiotic or collective aspect of an assemblage relates not to a productivity of language but to regimes of signs, to a machine of expression whose variables determine the usage of language elements' $(2004,100)$. Fortunately, Deleuze and Guattari do not only develop this political terminology in the abstract. In A Thousand Plateaus, Deleuze and Guattari work through this new theory by taking a number of examples. Perhaps the most enlightening example for our purposes comes with Deleuze and Guattari's analysis of the role of the line of flight in the transformation from the feudal assemblage to a capitalist assemblage. By looking at this example in some detail, we 
will gain a clearer picture of the role that the concept of the line of flight plays in the political philosophy of $A$ Thousand Plateaus and we will be in a better position to see how this concept might be used to theorise a post-capitalist politics.

According to Deleuze and Guattari, feudalism is partially composed of a machinic assemblage of bodies, which includes 'the body of the earth and the social body; the body of the overlord, vassal, and serf; the body of the knight and the horse and their new relation to the stirrup; the weapons and tools assuring a symbiosis of bodies' $(2004,98)$. Some of the aspects of this corporeal assemblage can be understood as molar lines of segmentarity. For example, the rigid organisation of fields on the earth, or the strict differentiation between the lord and the serf. The feudal assemblage is also composed of more supple lines of molecular segmentation, which might include the meandering bodies of water, or the encroaching forests, which impinge on the fields, or the bodies of travelling troubadours who cut across the stratified social divisions. However, as well as being composed of these bodies, feudalism is governed by a particular collective assemblage of enunciation, which involves the statements and expressions specific to the feudal social order. These include, 'the juridical regime of heraldry, all of the incorporeal transformations, in particular, oaths and their variables (the oath of obedience, but also the oath of love, etc.)' $(2004,98)$. Once again, on the side of enunciation, it is possible to pick out both the molar and the molecular lines that compose the assemblage.

What is of most interest to us here, however, is the way in which Deleuze and Guattari show how the feudal assemblage is composed from the very beginning by certain lines of flight which escape from it in all directions. They take at least two examples of lines of flight that operate in the feudal assemblage, namely the knight of courtly love and the merchant. Speaking of the knight, Deleuze and Guattari discuss the 'complex assemblage of secrecy in courtly love' which is characterised by the 'celerity of the war machine against the gravity of the State apparatus' $(2004,319)$. The knight of courtly love escapes from the rigid social stratification of feudal life on a passional and romantic line that allows him to '[j]ump from one assemblage to another' $(2004,295)$. It is important to point out here that unlike the line of flight which connects the wasp to the orchid, the line of flight of the courtly knight is continually blocked from ever making a real connection with another assemblage. In their analysis of the 'flows that escape' from the 'micropolitics of the Middle Ages', Deleuze and Guattari will attempt to show that, while the feudal assemblage 'can only function with decoded flows', the apparatuses of feudalism 'do not let them stream together; they perform topical conjunctions that stand as so many knots or recodings' $(2004,499)$. In this sense, the knight of courtly love continually draws a line of flight, but one which is always cut short of producing a transformation in the social field.

The lines of flight drawn by the merchant class do not suffer the same fate. It is these lines that Deleuze and Guattari credit with the transformation that brought about the end of feudalism and the birth of capitalism. This observation originally appears in 
Anti-Oedipus, where Deleuze and Guattari show how the despotic rule of the feudal lords only collapses when 'the flow of merchant capital' connects one feudal regime to another, disrupting the despotic centralisation of power $(2012,237)$. When this occurs, the previous feudal system of guilds breaks down, bringing about both 'the decoding of the worker' and 'the deterritorialization of wealth' $(2012,246)$. It is the conjunction of these two deterritorialised flows that brings about the historical birth of capitalism. ${ }^{8}$ According to this analysis, feudalism does not fail when its internal contradictions become dialectically expressed in revolution. Instead, the feudal assemblage is transformed when the lines of flight that constitute it are not cut off and are able to connect up with something outside of the assemblage. In $A$ Thousand Plateaus, Deleuze and Guattari are clear that it is the 'merchant bourgeoisie of the cities' that acts as the 'cutting edge of deterritorialization' that escapes feudal domination and acts as the line of flight that will produce a new capitalist assemblage $(2004,243){ }^{9}$ Specifically, it is by drawing quantitative equivalences between the value of goods in different feudal regions that the merchants produced a global market which undercut the qualitative power of the feudal lords. It is this shift from local centres of qualitative power to a generalized quantitative axiomatic of the market that Deleuze and Guattari see as the birth of capitalism.

What is important to note in Deleuze and Guattari's analysis of both the knight of courtly love and the merchant bourgeoisie, is that while they both constitute lines of flight in the feudal assemblage, these lines only bring about a transformation when they connect up with something outside of themselves. Deleuze and Guattari regularly come back to the fact that these connections are not historical necessities, but contingent events that could have happened otherwise (2004, 408; 474). In both AntiOedipus $(2012,214 ; 244)$ and $A$ Thousand Plateaus $(2004,499)$, Deleuze and Guattari ask why capitalism did not arise in China in the fourteenth century, despite the fact that the technological and material conditions seemed to be right. ${ }^{10}$ Their answer is that the lines of flight produced by merchants crossing the smooth space of the sea were recaptured by the state and were not allowed to conjugate. Speaking of the 'adventure of China', Deleuze and Guattari write that, 'in spite of its very high level of technology in ships and navigation, it turned its back on its huge maritime space, saw its commercial flows turn against it and ally themselves with piracy, and was unable to react except by a politics of immobility' $(2004,426)$. This insight is important when we consider the role that the concept of the line of flight plays in Deleuze and Guattari's political philosophy. Lines of flight are not necessarily emancipatory, and they do not always lead to transformation. More often than not, lines of flight are blocked or are recaptured by the assemblage from which they escape. ${ }^{11}$ This difference between a line of flight that is blocked and a line of flight that produces a machinic transformation in an assemblage will be central to the anti-capitalist politics developed in A Thousand Plateaus. However, in order to see how this distinction is made apparent, it will be necessary to turn our attention to the collective assemblage of enunciation that is operative under capitalism. 


\section{The Four Regimes of Signs and Their Lines of Flight}

As we have seen, every assemblage is composed of two sides: a machinic assemblage of bodies and a collective assemblage of enunciation. In order to analyse the role that the concept of the line of flight plays in Deleuze and Guattari's assessment of capitalism - at least as it is given in A Thousand Plateaus - it will now be useful to look in more detail at the organisation of the collective assemblage of enunciation of the capitalist assemblage. In order to do this, we will need to turn briefly to two other conceptual innovations that Deleuze and Guattari introduce in A Thousand Plateaus, namely the use of 'order words' to bring about 'incorporeal transformations' $(2004,89)$, and their solidification into 'regimes of signs' $(2004,123)$.

To understand how the two sides of an assemblage interact, we must give some account of how statements can be used to organise bodies. According to Deleuze and Guattari's assessment of linguistics, this occurs when the 'illocutionary' dimension of speech is used to bring about an 'incorporeal transformation' in a state of affairs (2004, 87-89). Deleuze and Guattari offer a number of examples of this process: when a judge says the word 'guilty' the body of the defendant is instantaneously transformed into the body of a convict $(2004,89)$; while the process of ageing is continuous, the sudden shift from being a worker to being retired is a transformation brought about by a certain regime of enunciation $(2004,89)$; when a hijacker on an aeroplane states his intentions, there is an immediate 'transformation of the passengers into hostages, and of the plane-body into a prison-body' $(2004,90)$. In each of these cases, the collective assemblage of enunciation determines the relations of bodies. It is the words, said by the right person at the right moment, which mark an instantaneous event in which the relations of the social field are suddenly shifted. This illocutionary dimension of language is political, because not everyone's speech has the same power. When a judge says 'you are guilty' then your body is transformed, but if you were to say the same to him or her, then nothing would change. The words that bring about incorporeal transformations are known as 'order words' because they can be used to organise bodies in a specific way $(2004,84-88) .{ }^{12}$

According to Deleuze and Guattari's analysis, the illocutionary dimensions of language are in a state of flux, so that at different moments in history, and in different sociocultural contexts, different words, spoken by different people, will act as order words. Despite these changes, it is also possible to discern relatively stable systems of illocution operating at different historico-geographical junctures. These stable systems of the use of language to organise bodies are named 'regimes of signs' $(2004,92)$. As Deleuze and Guattari clarify: 'We call any specific formalization of expression a regime of signs', and therefore a 'regime of signs constitutes a semiotic system' $(2004,123)$. Earlier on, we saw how feudalism must be understood not only as a particular mixture of bodies, but also as a system of enunciative practices that are contained in a system of workers guilds and oaths of obedience, and in the legal structures of heraldry. These semiotic norms constitute the regime of signs of feudalism. 
In A Thousand Plateaus, Deleuze and Guattari pick out four different regimes of signs, which they see recurring throughout the history of socio-political formations. Importantly for us, each of these regimes is partially constituted by lines of flight and is partially defined by the way it relates to those lines of flight. What is more, Deleuze and Guattari will claim that capitalism is nothing other than a specific mixture of two of these regimes of signs, and that it therefore fluctuates between two different ways of relating to its lines of flight.

The four different regimes of signs that Deleuze and Guattari pick out are named as the 'presignifying', 'signifying', 'postsignifying', and 'countersignifying' regimes (2004, 130-131). The presignifying regime of signs is the semiotic system of what Deleuze and Guattari had called primitive societies in Anti-Oedipus. It operates by keeping a range of polyvocal forms of expression in operation at the same time, so that various forms of enunciation, including 'corporeality, gesturality, rhythm, dance, and rite' can 'coexist heterogeneously with the vocal form' (2004, 130). Under this regime, signs are used to make marks on the flesh and on the earth, in order to specify to which order of expression a body belongs. This regime of signs can be diagrammed by a series of parallel lines which are continually kept separate from one another. Under the presignifying regime of signs, lines of flight are taken to be negative and destructive, because they threaten to cut across the different parallel registers of expression, bringing about the end of the regime. As such, lines of flight are continually warded off. The signifying regime of signs takes hold exactly when the presignifying regime fails to ward off its lines of flight. When this happens, an equivalence is created between the different polyvocal forms of expression and all use of signs becomes organised around a single centre of reference. Subsequently, all language becomes signifying in the strict sense of a structural linguistics. ${ }^{13}$ In the signifying regime 'the network of signs is infinitely circular' leading to a semiotics based on a 'multiplicity of the circles or chains', in which the centre of the circle becomes an always-implicit centre of power $(2004,125)$. This regime of signs is equivalent to the despotic mode of social organisation described in Anti-Oedipus, and the centre of this system of reference is the face of the despot, which acts as the wall on which signs are inscribed. In the signifying regime, lines of flight are not warded off, but they are expelled, or cast out, from the circular signifying web of social life. The example that Deleuze and Guattari take is the scapegoat: 'In the signifying regime, the scapegoat represents a new form of increasing entropy in the system of signs... it incarnates that line of flight the signifying regime cannot tolerate' $(2004,128)$. Through the incorporeal transformation by which an animal is made into a scapegoat and cast out into the desert, the signifying regime of signs nullifies the dangers of the line of flight, and casts them out of society for good.

The postsignifying and the countersignifying regime both describe situations that occur when the dominance of the signifying regime fails. While the presignifying and the signifying regimes both framed lines of flight as negative aspects of the collective 
assemblage of enunciation, which must be nullified or expelled in some way, both the postsignifying and the countersignifying regimes are constructed on a line of flight. The postsignifying regime is produced when the line of flight that is cast out of the despotic signifying system is affirmed by a subject, who uses this line to define their subject position. The example that Deleuze and Guattari take here is the Jewish escape from Egypt, in which the arc of the covenant becomes 'a little portable packet of signs', something which had been cast out of the Egyptian signifying regime as a 'negative line of flight occupied by the animal or scapegoat' but which the Jewish people affirm and make into a positive line of flight, or deterritorialisation: 'It is we who must follow the most deterritorialized line, the line of the scapegoat, but we will change its sign, we will turn it into the positive line of our subjectivity, our Passion, our proceeding or grievance' $(2004,135)$. Deleuze and Guattari refer to this regime as 'subjective' and 'passional' $(2004,134)$. In signifying regimes, statements gain their efficacy by referring back to the despot as the totalizing centre of all power, but in subjectifying regimes, statements gain their efficacy by extending the passional proceeding of a single authoritarian aim. For this reason, Deleuze and Guattari use the distinction between the signifying and the postsignifying regimes to mark the difference between totalitarianism and authoritarianism. Rather than being diagrammed by a radiating series of circles, the postsignifying regime is diagrammed by a series of lines of flight, which each end in a 'black hole' (2004, 186-189): the passional proceeding of the postsignifying regime always fails, but it is taken up again and again. In Deleuze and Guattari's example, the Jewish people use the arc to build a new temple, but when this is destroyed their proceeding must begin again.

The countersignifying regime is also organised on a line of flight that escapes from the signifying regime. However, unlike in the postsignifying situation, in this case the line of flight does not remain singular and subjective, but connects up with a multiplicity of other lines of flight in order to draw what Deleuze and Guattari will call a 'smooth space' of deterritorialisation $(2004,416)$. Under the countersignifying regime, signs are used to produce 'a mobile and plural distribution' of the social field, 'which arrives at arrangements rather than totals, distributions rather than collections, which operates more by breaks, transitions, migration, and accumulation than by combining units' $(2004,131)$. If the signifying regime is operative in despotic states, and the postsignifying regime is operative in social groups who are fleeing the state form, then the countersignifying regime can be found in nomadism. ${ }^{14}$ Each of the four regimes of signs discussed by Deleuze and Guattari is a particular organisation of the collective assemblage of enunciation, which forms one side of the social assemblage. In each case, it is the regime of signs that determines which order words will bring about which incorporeal transformations: under the signifying regime of signs that is operative in sedentary state societies the words of the judge have the power to transform the relations between bodies, but this only works because the words of the judge refer back to the power centre of the despot who sits at the axis of the circular network of signs. In a countersignifying semiotic, the judge's words would have no more power than the words of the defendant. ${ }^{15}$ 
In A Thousand Plateaus, Deleuze and Guattari do not align any of these four regimes of signs with capitalism. Instead, they see capitalism as a very specific mixture of the signifying regime of significance and the postsignifying regime of passional subjectivity. They say that 'the semiotic of capitalism' is defined by a 'state of mixture in which signifiance and subjectification effectively interpenetrate' $(2004,202)$. What this means is that on the side of the machinic assemblage of bodies, capitalism is produced by a combination of the state form and the lines of flight that escape from the state. If we remember that the signifying regime relates to lines of flight as something negative, which must be cast out of the social field, and if we remember that the postsignifying regime takes lines of flight to be positive movements that must be affirmed, then we will see that Deleuze and Guattari are suggesting that capitalism has a paradoxical relationship with lines of flight. As such, capitalism works by finding a kind of balance between deterritorialisation and reterritorialisation: capitalism needs the state form - and its accompanying signifying regime - in order to provide a kind of stability, which will recapture the lines of flight that it continually produces. It is this dual-movement that explains capitalism's need for constant growth. ${ }^{16}$

In the previous section, we saw that Deleuze and Guattari do not follow the traditional Marxist technique of defining each social formation by its basic mode of production, and by the ideological superstructure to which it gives rise. Instead, in A Thousand Plateaus, each social form is understood to be an assemblage of heterogeneous elements, one side of which is the machinic assemblage of bodies and the other is a collective assemblage of enunciation. Taking feudalism as an example, we also saw that each socio-political assemblage is defined by the different lines that compose it, including its molar lines, its molecular lines, and its lines of flight. Specifically, we saw that feudalism was partially composed of the line of flight of the knight of courtly love, which is continually blocked so that it does not bring about a transformation in the social field. Finally, we saw that feudalism was finally overcome when the lines of flight of the merchant class could not be recaptured and, linking up with each other, produced a transformation in the assemblage. We are now in a position to see that capitalism - which is also an assemblage with two sides - has, as its collective assemblage of enunciation, a mixed semiotic. This means that it has a particularly complex relationship with the lines of flight that compose it. On the one hand these lines are required and are treated as positive when they push beyond the boundaries of the state, and on the other hand they are treated as negative when they threaten to go too far, at which point they must be recaptured by the tools of the despotic regime. The relationship between homosexuality and capitalism can provide a good example here: homosexuality constitutes a line of flight that threatens the formation of the nuclear family and so is treated by the State as a negative line that must be expelled; however, this escape from the State form is required by capitalism, which takes this revolutionary line and reterritorialises a market on it; what we see in the capitalisation of homosexual life - for example in the commodification of Pride - is typical of the way 
in which capitalism expands and survives by using lines of flight to move beyond the state, but then recaptures these lines as part of its own axiomatic of the market.

This insight is important for anyone attempting to read Deleuze and Guattari's work for insight into the political activity of bringing about a post-capitalist future. While feudalism could be overcome simply by following the lines of flight that reach outside of the socio-political assemblage, this technique will not work with capitalism, which routinely internalises these lines as part of its operation. What, then, are the modes of becoming that will be successful in bringing about an effective transformation of capitalism? Deleuze and Guattari provide at least two different answers to this question in A Thousand Plateaus, both of which can only be fully articulated by using the concept of the line of flight and both of which we have already touched upon in this article. The first answer, which concerns the collective assemblage of enunciation, involves the four regimes of signs we have just discussed. If capitalism is nothing other than a mixture of the signifying and the postsignifying regimes, then drawing lines of flight will not be enough to transform it. However, if those lines of flight can compose a countersignifying regime, rather than a postsignifying one, a world outside of capital may be possible. The second answer relates to the possibilities of becoming on the side of the machinic assemblage of bodies. Just as the wasp is transformed when a line of flight connects it to the orchid so that a becoming-wasp of the orchid is matched by a becoming-orchid of the wasp, capitalism can be transformed, according to Deleuze and Guattari, when processes of becoming are instigated that transform capitalist bodies into something new. In the final section of this paper we will see how Deleuze and Guattari combine these two practices and how it is the concept of the line of flight that allows them to do so.

\section{Lines of Flight as Political Becomings}

In A Thousand Plateaus, Deleuze and Guattari continually remind us that 'there is no social system that does not leak from all directions, even if it makes its segments increasingly rigid in order to seal the lines of flight' $(2004,225)$. This is especially true of capitalism, which is partially composed of lines of flight that it must repeatedly recapture. As such, lines of flight are not inherently anti-capitalist. What is important is not the mere existence of the lines of flight that escape from the social order of capital, but the way in which these lines are conjugated with one another. ${ }^{17}$ On the side of the collective assemblage of enunciation, we can say that the lines of flight that compose the diagram of the postsignifying regime of signs are part of the capitalist machine, whereas the lines of flight that compose the countersignifying regime of signs have the power to destroy capitalism. Perhaps the best way to get a handle on what Deleuze and Guattari have in mind here, is to look at the way in which the writing style of $A$ Thousand Plateaus instantiates the mode of expression that it is also advocating.

As the countersignifying semiotic is the mode of expression of nomadic societies, it is not surprising that Deleuze and Guattari will refer to their own writing as a practice of 
'nomadology' $(2004,48)$. In brief, Deleuze and Guattari's book is an analysis of a wide range of different fields of expression, including geology, biology, linguistics, ethnology, psychoanalysis, political theory, and mathematics. In each of these fields, Deleuze and Guattari attempt to find the lines of flight that are escaping from the disciplinary assemblage. However, simply finding these moments of escape is not enough. If we take any particular science by itself, then we will see that it has developed over time because it includes a nomadic element which pushes the discipline forwards. However, what we also find is that these moments of escape are always recaptured into the science. Perhaps Deleuze and Guattari's favourite example of this is the differential calculus, which is like a line of flight that rips apart the edifice of mathematics, but which is then rehabituated into the discipline in a nullified form $(2004,536)$. The transdisciplinary activity of $A$ Thousand Plateaus consists in finding the lines of flight that escape from the different disciplines and connecting them up together. It is only by connecting up the various lines of flight that it is possible to produce a mode of expression that will not simply be recaptured by the signifying regime of a royal science. This is the first political lesson of $A$ Thousand Plateaus: in order to transform the enunciative aspect of contemporary society into something post-capitalist, it is necessary to conjugate the lines of flight that escape from each of our different social modes of speech and connect them together to produce a nomadic and counter-signifying smooth space of enunciation. ${ }^{18}$

Experimenting with modes of expression is one thing, but this practice would be useless if it was not accompanied by a commensurate mode of experimentation on the side of the machinic assemblage of bodies. As in the case of the modes of expression, the task here will not simply be to draw lines of flight, but to make them come together in such a way that they compose a new set of relations that exist outside of the capitalist dynamic. The example we took at the beginning of this paper, of the machinic becoming of the wasp-orchid, can provide us with a model for what it might look like to compose a line of flight that can bring about a transformation in the relations of bodies. Throughout $A$ Thousand Plateaus, Deleuze and Guattari suggest a large range of other modes of becoming, which are specifically designed to act as lines of flight that can help human bodies escape from the capitalist social form. These include 'becomings-woman, becomings-animal, becomings-molecular, [and] becomingsimperceptible', all of which are said to be induced on 'lines of flight' $(2004,311)$. The concept of a 'becoming' relates to the concept of the 'line of flight' in the following way: if all bodies are assemblages, then they are partially composed by the external relations that they maintain with other bodies; the lines or 'fibers' that cross the boundaries between different assemblages and connect these bodies together are the lines of flight. As Deleuze and Guattari put it: 'A fiber stretches from a human to an animal, from a human or an animal to molecules, from molecules to particles, and so on to the imperceptible... A fiber strung across borderlines constitutes a line of flight or of deterritorialization' (275). However, just as lines of flight are not necessarily anticapitalist, processes of becoming do not hold any inherent relationship with politics. 
The question still remains, which modes of becoming will be effective in the specific case of an anti-capitalist politics, and how can they be combined?

In response to this, it is important to recognise that the specific modes of becoming that Deleuze and Guattari discuss in A Thousand Plateaus are each designed to offer a line of flight which will escape one of the social stratifications that is operative in capitalism. Deleuze and Guattari see the three 'principle strata binding human beings' in contemporary life as 'the organism, signifiance and interpretation, and subjectification and subjection' $(2004,148)$. While the first of these relates to the way in which our bodies are organised as human, the latter two correlate with the way in which the signifying and the postsignifying regimes of signs impose signifiance and subjectivity upon us. In order to combat these capitalist social stratifications, Deleuze and Guattari prescribe three modes of becoming that respond to them, namely 'the (anorganic) imperceptible, the (asignifying) indiscernible, and the (asubjective) impersonal' (2004, 308). Deleuze and Guattari also point out that 'the semiotic of capitalism' is the 'semiotic of modern White men' $(2004,202)$. What this means is that the process of becoming-indiscernible, which will lead us away from the signifying regime of signs, must go by way of a series of other becomings. Because the majoritarian centre of resonance is the Christian, adult, white man, the required modes of becoming-minoritarian will include a becoming-woman, a becoming-Jewish, a becoming-child, a becoming-animal, and a becoming-black $(2004,321) .{ }^{19}$ Like the previous modes of becoming, Deleuze and Guattari will remind us that 'becomingsanimal' and 'becoming-woman' are composed 'on a line of flight' (2004, 273; 303-305). The final point to make here, regarding the various modes of becoming discussed in A Thousand Plateaus, is that it is through these modes of becoming that one makes oneself a Body without Organs. Each mode of stratification is an organisation of the body and each mode of becoming is an escape from such an organisation. The process of making oneself a Body without Organs is precisely the task of combining the different modes of becoming discussed in the text, in order to simultaneously escape from the totality of the capitalist social strata $(2004,178)$.

On both the side of the collective assemblage of enunciation and the machinic assemblage of bodies, the lines of flight that will enable the transformation of capitalism already exist as part of the social assemblage. Modes of expression are always coming apart, scientific disciplines are always escaping from themselves, bodies are always resisting the social stratifications that are imposed on them. The political task that Deleuze and Guattari lay out in A Thousand Plateaus is to find the lines of flight that are already escaping, to follow them, and to make them connect up with one another. However, the difficulty that we face here is that the various lines of flight that we have discussed so far may not be easily combined. As Deleuze and Guattari put it: 'There is no assurance that two lines of flight will prove compatible, compossible. There is no assurance that the body without organs will be easy to compose' $(2004,226)$. The potential incompatibility of lines of flight, and the fact that '[n]o one can say where the line of flight will pass', means that the only way to proceed 
is via a practice of experimentation $(2004,276)$. The political experiments that we can conduct - designed to test what a body can do - are experimental in the strict sense that we cannot know in advance how they will turn out. For example, we simply do not know what will happen when we combine a process of becoming-animal with a transdisciplinary practice of reading ethnology alongside geology. It may be the case that these lines of flight conjugate together, and a transformation occurs between the two assemblages in question. Alternatively, it may be the case that, in this instance, '[i]nstead of making a body without organs... the causal line, creative line, or line of flight immediately turns into a line of death and abolition' $(2004,314)$. The only possible response to these dangers is to practice caution. As Deleuze and Guattari warn the reader in the conclusion of $A$ Thousand Plateaus: 'Every undertaking of destratification (for example, going beyond the organism, plunging into a becoming) must therefore observe concrete rules of extreme caution' $(2004,554)$.

For Deleuze and Guattari, the social formation of capitalism is like all other social forms - and like all organic and physical forms - in that it is an assemblage composed of molar lines, molecular lines, and lines of flight. However, unlike some social forms, capitalism has a mixed semiotic, which means that the lines of flight that compose it play an ambivalent role, sometimes working as positive and active lines of subjectivity, and sometimes being treated as threats to the state that must be cut off at every turn. The fact that capitalism is an assemblage means that any anti-capitalist politics must engage with lines of flight, however the fact that capitalism has internalised its lines of flight in this way means that anti-capitalist experimentation with lines of flight must be extremely cautious. Whether on the side of enunciation, or on the side of bodies, these experiments can become destructive and suicidal lines of flight, with no potential to produce a post-capitalist social field. ${ }^{20}$

\section{Conclusion:}

The concept of the line of flight is used throughout $A$ Thousand Plateaus. Not only does it inform Deleuze and Guattari's analysis of the relationship between machinic assemblages and collective assemblages of enunciation, but it also allows Deleuze and Guattari to theorize the transformation of the concrete assemblages - be they physical, organic, or socio-political - that are composed of these two aspects. What is more, because concrete assemblages are said to 'effectuate the abstract machine', the concept of the line of flight is also central to Deleuze and Guattari's analysis of the functioning of abstract machines (2004, 79; see also 161-162 \& 246). As if this wasn't enough, Deleuze and Guattari also use the concept of the line of flight in order to explain their own practice of rhizomatic thinking. ${ }^{21}$ To think rhizomatically is to draw lines of flight which will map on to either the machinic assemblages or the collective assemblages of enunciation that one is thinking about (2004, 13-16). Given all of this, it should not be surprising to find that Deleuze and Guattari use the concept of the line of flight over two hundred times in A Thousand Plateaus and it appears at least once in every plateau. 
This article has offered a characterisation of the concept of the line of flight by looking at the way in which Deleuze and Guattari apply this concept in their attempts to think through a specific problem, namely the problem of the transformation of socio-political assemblages. Along the way, it has been possible to clarify the theory of political power that sometimes remains implicit in Deleuze and Guattari's later work, especially as it reworks and responds to Marx's political terminology. ${ }^{22}$ However, the main purpose of this analysis has been to show the central features of the concept, as it is applied in A Thousand Plateaus. What we have seen is that lines of flight are one of the three kinds of lines that operate in any assemblage. These lines escape the bounds of the assemblage and can make it 'blow apart' $(2004,16)$, but they are also essential for its genesis and can be thought of as 'the primary line' in an assemblage $(2004,226)$. As such, it is through an analysis of these lines that it is possible to see the way in which transformation is not something alien to the assemblages that compose the world. The socio-political assemblage of capitalism - much like the wasp, the orchid, or feudalism - is partially composed of lines of flight. While it may hold an ambivalent relationship with these lines, it is only through their activity that the assemblage will ever be transformed.

\section{Bibliography:}

Bell, Jeffrey (2018) 'Postulates of Linguistics', A Thousand Plateaus and Philosophy, ed. Somers-Hall, Bell, and Williams, Edinburgh: Edinburgh University Press

Bonta, Mark \& John Protevi (2006) Deleuze and Geophilosophy: A Guide and Glossary, Edinburgh: Edinburgh University Press

Colebrook, Claire (2009) 'Introduction to Deleuze and History', Deleuze and History, ed. Jeffrey A. Bell and Claire Colebrook, Edinburgh: Edinburgh University Press, pp. $1-33$

Deleuze, Gilles (2001) Empiricism and Subjectivity: An Essay on Hume's Theory of Human Nature, trans. Constantin Boundas, New York: Columbia University Press

Deleuze, Gilles (2006) Nietzsche and Philosophy, trans. Hugh Tomlinson, New York: Columbia University Press

Deleuze, Gilles \& Félix Guattari (2012) Anti-Oedipus, trans. Robert Hurley, Mark Seem, and Helen R. Lane, London: Continuum

Deleuze, Gilles \& Félix Guattari (2004) A Thousand Plateaus, trans. Brian Massumi, London: Continuum 
Dolphijn, Rick, and Iris van der Tuin (2013) 'A thousand tiny intersections: Linguisticism, feminism, racism and Deleuzian becomings', Deleuze and Race, ed. Arun Saldanha and Jason Michael Adams, Edinburgh: Edinburgh University Press

Guattari, Félix (2015) Psychoanalysis and Transversality, trans. Ames Hodges, New York: Semiotext(e)

Jackson, George (1994) Soledad Brother: The Prison Letters of George Jackson, Chicago: Chicago Review Press

Koerner, Michelle (2011) 'Line of Escape: Gilles Deleuze's Encounter with George Jackson', Genre 44:2, pp. 157-180

Lundy, Craig (2013) 'Why wasn't Capitalism born in China? - Deleuze and the Philosophy of Non-Events', Theory and Event 16:3, pp. 1-6

Mandel, Ernest (1990) 'Introduction', in Capital: Volume 1, Karl Marx, trans. Ben Fowkes, London: Penguin

Massumi, Brian (2004) 'Notes on the Translation and Acknowledgments', A Thousand Plateaus, Deleuze and Guattari, London: Continuum, pp. xvii-xx

Nail, Thomas (2017) 'What is an Assemblage?', SubStance \#142 46:1, p23

Philips, John (2006) 'Agencement/Assemblage', Theory Culture Society 23, p108

Sibertin-Blanc, Guillaume (2016) State and Politics: Deleuze and Guattari on Marx, trans. Ames Hodges, South Pasadena: Semiotext(e)

Thornton, Edward (2017) 'The Rise of the Machines: Deleuze's Flight from Structuralism', The Southern Journal of Philosophy, 55:4, pp. 454-474

Young, Eugene, Gary Genosko \& Janell Watson (2013) The Deleuze and Guattari Dictionary, London: Bloomsbury

\section{Notes:}

${ }^{1}$ In the conclusion of this article I will also attempt to place Deleuze and Guattari's political usage of this concept in the context of their broader philosophy of transformation.

2 There are two important lineages of the concept of the line of flight that I will not be able to discuss in depth in this article. First, the French term ligne de fuite has a specific 
meaning in the theory of linear perspective. While two parallel lines meet at an infinitely receding vanishing point, or point de fuite, two parallel planes meet at a horizonal line, or a ligne de fuite. This connection is rarely discussed in the literature, but it nodded to by a number of translators. See Massumi (2004, xvii), Bonta and Protevi (2006, $106)$, and Young, Genosko and Watson (2013, 183-185). Second, the concept of the ligne de fuite owes much to Fernand Deligny's use of the concept of the wander line, or ligne d'erre, in his therapeutic practice of mapping (2015, 227-251). Deleuze and Guattari reference Deligny's work in $A$ Thousand Plateaus in order to make this connection (2004, 16 \& 224).

${ }^{3}$ For a more detailed analysis of this concept, see Philips $(2006,108)$ and Nail $(2017$, 21-37). Concerning the role that the concept of the line of flight plays in determining the relations that an assemblage has with its outside, it may also be possible to see the use of this concept as a development of Deleuze's early observations on Hume's theory of the externality of relations. For more on this see Deleuze's book on Hume (2001, 66).

${ }^{4}$ When Deleuze and Guattari speak of the functioning of a machinic assemblage it should be kept in mind that such functioning cannot be dissociated from an activity of desire and that for them "breaking down is part of the very functioning of desiring machines" $(2012,34)$.

5 This understanding is drawn in part from Deleuze's Nietzschean conception of force $(2006,6)$ and in part from Guattari's anti-structuralist account of unconscious desire (2015, 318-329).

${ }^{6}$ This line is given within a discussion of the work of Samuel Butler, who Deleuze and Guattari credit with being the first to move beyond the distinction between mechanism and vitalism.

7 This section is quoted by Deleuze and Guattari in Anti-Oedipus (2012, 313).

8 It is interesting to note that while in Anti-Oedipus Deleuze and Guattari specifically characterise this as a historical moment, in $A$ Thousand Plateaus this event is not described as a historical development, but as a turning point in the expression of an abstract machine. It is partly for this reason that the different socio-political assemblages are understood to relate to one another on a geological/geographical, rather than a historical, plane. For more on this, see Bonta and Protevi (2006, 32-45). ${ }^{9}$ It is important to point out here that Deleuze and Guattari do not confuse the activity of the line of flight with the process of deterritorialisation. They are clear in A Thousand Plateaus that assemblages have a vertical axis determined by the two poles of deterritorialisation and reterritorialisation and a horizontal axis determined by what Deleuze and Guattari call the double articulation of content and expression. Lines of flight cut across the stratifications of an assemblage and its territorial boundaries and cannot be restricted to only one of these axis $(2004,98)$.

${ }^{10}$ For more on the specific question of China, see Lundy's article on this topic (2013).

11 This is a theme throughout Deleuze and Guattari's Capitalism and Schizophrenia series and maps on to the claim in Anti-Oedipus that '[t]here is a whole world of difference between the schizo and the revolutionary: the difference between the one who escapes, and the one who knows how to make what he is escaping escape' (2012, 374).

12 For a more in-depth study of the role of order words in bringing about incorporeal transformations, see Bell (2018).

13 Deleuze and Guattari make this clear by stating that signifying regimes of signs relate to 'the situation Levi-Strauss describes' in his structuralist anthropology (2004, 
124). For more on Deleuze and Guattari's relationship with structuralism in the Capitalism and Schizophrenia series, see Thornton (2017).

14 Deleuze and Guattari are very careful here to specify that there are different historical forms of nomadism: they say that it is only 'the fearsome, warlike, and animal-raising nomads' who instantiate the countersignifying semiotic, 'as opposed to hunter nomads' who remain in a postsignifying semiotic $(2004,131)$.

15 Deleuze and Guattari do not give any explicit examples of incorporeal transformations that would operate in a countersignifying regime of signs. The closest they come is probably in their discussion of 'numbering number' and its use in organising nomadic military groups into units of "tens, fifties, hundreds, thousands" $(2004,131)$. The title of $A$ Thousand Plateaus, and the way in which this numbering is supposed to produce a distribution of analysis in which each plateau resonates with the others, could also be taken as an example of the use of numbering number as an order word bringing about an incorporeal transformation.

16 This point is prefigured by Deleuze and Guattari's claim in Anti-Oedipus that capitalism is characterised by 'a twofold movement of decoding or deterritorializing flows on the one hand, and their violent and artificial reterritorialization on the other' (2012, 37).

17 In a certain sense, Deleuze and Guattari's politics of the conjugation of different minor flows, all of which resist capitalism in their own way, can be seen as equivalent to a politics of 'intersectionality'. For more on this, see Dolphijn \& Van der Tuin (2013). 18 It is important to note here that, in line with Deleuze and Guattari's anti-utopianism, this smooth space of enunciation is not something attainable. Instead, what is important is to produce enunciative practices that tend towards smoothing rather than towards stratification.

19 The case of 'becoming-black' is probably the least well discussed in the secondary literature. This is important to note here because Deleuze and Guattari develop the concept of the line of flight in direct response to George Jackson's description of fleeing, while simultaneously looking for a weapon $(2004,321)$. For the direct reference see Jackson $(1994,328)$; for a brilliant analysis of this connection see Koerner (2011).

20 In Anti-Oedipus, Deleuze and Guattari see this as the danger of fascism: if the social field becomes deterritorialised, and if the oedipal organisation of desire is still functioning, then the line of flight's capacity to bring about transformation will only ever result in desire coming to desire its own subjugation $(2012,382)$.

${ }^{21}$ Deleuze and Guattari differentiate between the effects of rhizomatic thinking and arborescent thinking, as they are each applied to either concrete or abstract assemblages, through their analysis of the relationship of the 'plane of consistency' to the 'plane of organisation'. The concept of the line of flight is therefore also central to any understanding of the relationship between these two planes. As Deleuze and Guattari state: '[T] plane of consistency does not preexist the movements of deterritorialization that unravel it, the lines of flight that draw it and cause it to rise to the surface, the becomings that compose it. The plane of organisation is constantly working away at the plane of consistency, always trying to plug the lines of flight' (2004, 297).

22 For one of the only detailed analyses of this political theory, see Sibertin-Blanc (2016). 